\title{
Guideline and treatment algorithm for burn injuries
}

\author{
Ahmet Çınar Yastı, M.D., ${ }^{1,2}$ Emrah Şenel, M.D., ${ }^{3}$ Mutlu Saydam, M.D., ${ }^{4}$ \\ Geylani Özok, M.D., ${ }^{5}$ Atilla Çoruh, M.D., ${ }^{6}$ Kaya Yorgancı, M.D. ${ }^{7}$
}

\begin{abstract}
'Department of General Surgery, Hitit University Faculty of Medicine, Çorum;
${ }^{2}$ Ankara Numune Training and Research Hospital, Burn Treatment Center, Ankara;

${ }^{3}$ Department of Pediatric Surgery, Yıldırım Beyazıt University Faculty of Medicine, Ankara;

${ }^{4}$ Department of Esthetic, Plastic and Reconstructive Surgery and Burns Unit, Yunus Emre Governmental Hospital, Eskişehir;

${ }^{5}$ Department of Pediatric Surgery, Ege University Faculty of Medicine, Izmir;

${ }^{6}$ Department of Esthetic, Plastic and Reconstructive Surgery, Erciyes University Faculty of Medicine, Kayseri;

${ }^{7}$ Department of General Surgery, Hacettepe University Faculty of Medicine, Ankara
\end{abstract}

\begin{abstract}
As in many other countries, burn injuries are a challenging healthcare problem in Turkey. Initial management of burn patients is very important for future morbidity and mortality. Therefore, the Turkish Ministry of Health prepared "National Burns Treatment Algorithm" aided by the Scientific Burns Council. The basic aim of this algorithm is to guide physicians in the treatment of burn victims until they reach an experienced burns center. The content of this algorithm is first aid, initial management, resuscitation, and transfer policy. The Council started to work on this algorithm in 20I I. Various consultants, including general surgeons, pediatric surgeons, aesthetic, plastic and reconstructive surgeons, anesthesiologists, and intensive care physicians, revised the first draft and it was sent to eight education and research hospitals of the Ministry of Health, four universities, and seven non-governmental organizations. In the last quarter of 2012, the algorithm was finalized and approved by the Scientific Council, after which, it was approved by the Ministry of Health and published.
\end{abstract}

Key words: Algorithm; burn; guideline; treatment.

\section{Determining Burn Severity and On-Site Medical Attention}

\section{Determining Burn Severity}

Determining burn severity depends on the burned surface area, depth of burn and the involved body area.

I. Burned Surface Area: The 'rule of nines' can roughly estimate adult burns (Fig. Ia). However, more accurate diagrams are available for adults (Fig. Ib) and children (see Lund Browder's diagram), and a brief form of the diagram is shown in Fig. 2. For practical calculation, the outstretched palm with fingers together can be accepted as $1 \%$ of the body surface area for an individual (Fig. 3).

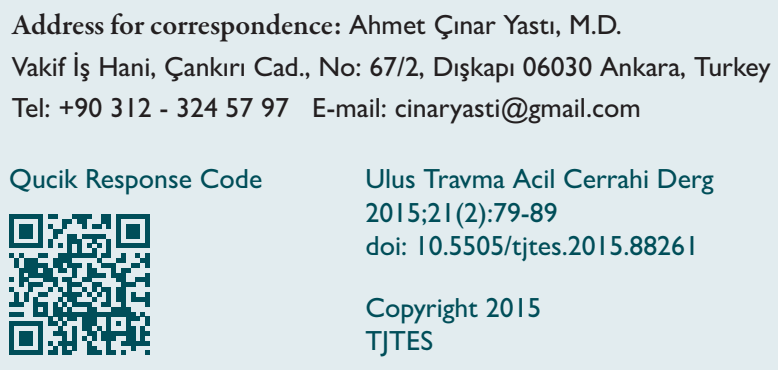

2. Depth of the Burn: Burns are classified as superficial and deep dermal in clinical practice.

In superficial burns, there is no or minimal dermal injury. These are first degree and superficial second degree burns, and usually heal in 3 weeks without any sequelae.

The dermis is partially or completely injured in deep dermal burns. They are classified as deep second, third and fourth degree regarding dermal injury and underlying deep tissues. These will usually heal in more than three weeks and usually require surgical intervention.

First Degree: $\quad$ Epidermis is intact, there is erythema, e.g.: sunburn

Second Degree: Epidermal integrity is damaged. If the injury is limited to the upper layers of dermis, it is superficial second degree; however, involvement of the deeper (reticular) layers leads to deep second degree burn. While superficial is much more painful, there is less pain and a blunt pressure feeling in deep burns.

Third Degree: All layers of the dermis are involved. The skin is hard, dark, dry, painless, thromboses 


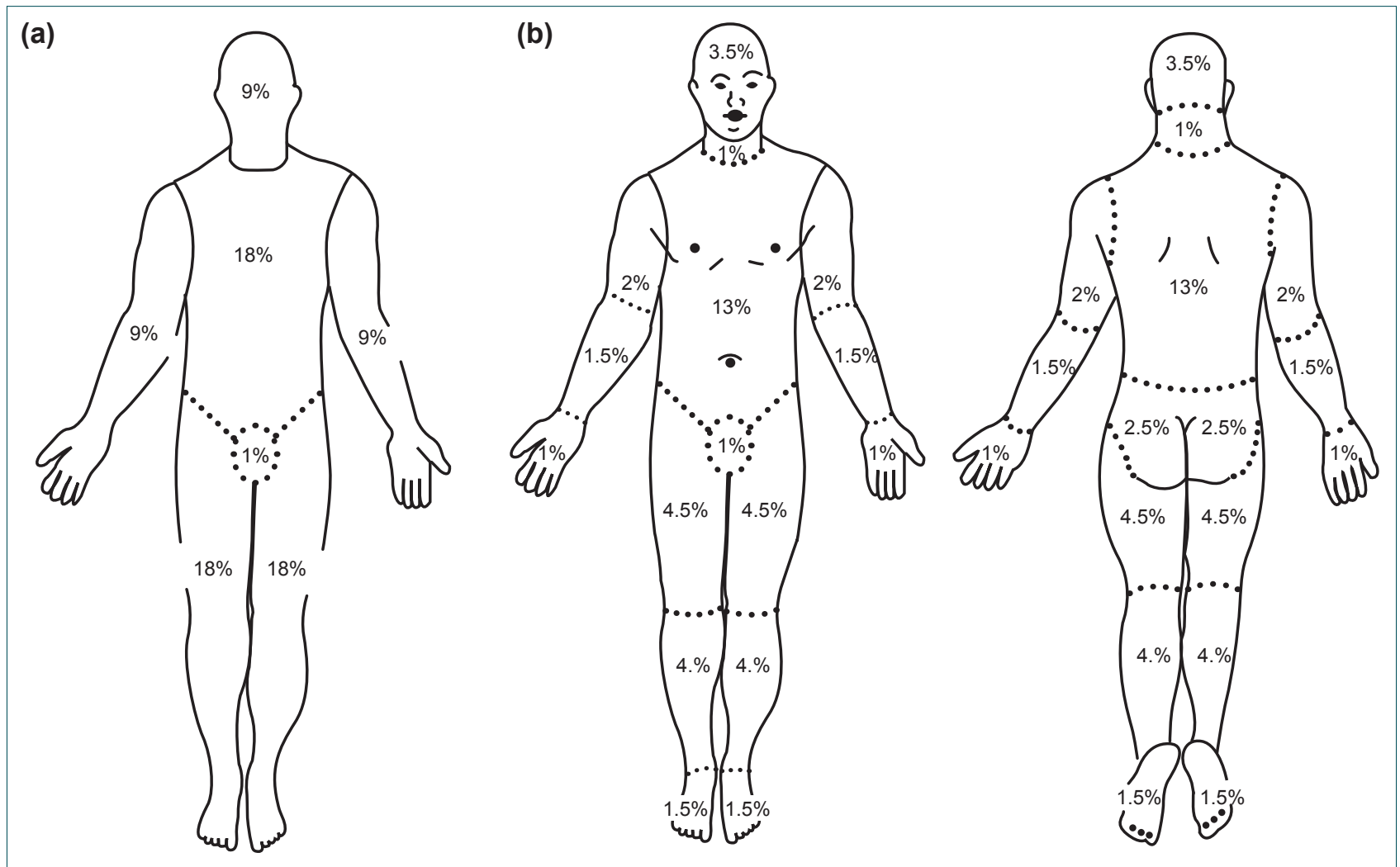

Figure 1. (a) The rule of nines diagram. (b) Schema for estimation of body surface area in adults.

inside the vessels, and there is typical burn eschar.

Fourth Degree: All layers of the skin, subcutaneous fat tissue and deeper tissues (muscles, tendons) are involved, and there is a carbonized appearance.

3. Burned Body Site: Burns of the eye, ear, face, hands, feet, and genitalia are 'special area burns' and should be treated at an experienced burns unit/center.

\section{Classification Burn Severity}

I. Minor Burns

a. Second degree adult burns less than I5\% TBSA

b. Second degree child burns less than 10\% TBSA

c. Third degree child or adult burns less than $2 \%$ TBSA

2. Moderate Burns

a. Second degree adult burns involving 15 to $25 \%$ TBSA

b. Second degree child burns involving 10 to $20 \%$ TBSA

c. Third degree child or adult burns involving 2 to $10 \%$ TBSA

\section{Major Burn}

a. In adults, second degree burns greater than 25\% TBSA

b. In children, second degree burns greater than $20 \%$ TBSA

c. Third degree burns greater than $10 \%$ in an adult or a child

d. Inhalation injury

e. Electrical burns

f. Burns with concomitant additional trauma (such as head trauma, intra-abdominal injury, fractures)

g. Burns during pregnancy

h. Co-morbidities adding significant risk to burns (such as Diabetes Mellitus, corticosteroid use, immune suppression)

i. Burns of the eye, ear, face, hand, foot, major joint and genitalia.

Minor burns can be treated as an outpatient or in a burns room. Moderate and severe burns must be hospitalized and treated in a burns unit/center.

\section{On-Site Medical Attention}

I. Airway, breathing and circulation should be assessed. In a multiple trauma patient, the 'forget the burn' principle is valid and the management of life threatening injury has priority.

2. Rescuing the victim from the burning premises and extinguishing the fire have priority.

3. In minor burns, the burned area should be kept under running tap water for 20 minutes within the first 15 minutes, and further burning should be stopped.

4. Hot liquid burns 




Figure 2. Lund-Browder schema.

- All wet clothes are removed

5. Flame burns

- The patient is removed from the heat source and moved from the scene to open-air; however, if not possible, the fire is extinguished.

- Carbon monoxide or smoke intoxication is checked and the patient is administered $100 \%$ oxygen.

- Requirement for endotracheal intubation is evaluated.

6. Electrical Burns

- Health care provider should be aware that the patient is likely to be injured in three different ways: real electrical injury via electric current, arc burns, and flame burns as a consequence of the electric current ignition.

- The electricity is turned off and/or the patient should be removed from the source,

- Requirement for immediate cardiopulmonary resuscitation is evaluated (especially in low voltage injuries)

- Sign or symptoms of multiple trauma, blunt or penetrating trauma must be checked,

7. Chemical Burns

- Dry chemicals are firstly brushed off, and then, should be rinsed with running water until the pain is relieved (this could take 60 minutes)

- Neutralizing agents are not recommended (contra- indication as may cause further heat)

A large intravenous line insertion is required for every major burn case and Ringer's lactate solution should be the choice of fluid resuscitation. Circulation, respiration, and urinary output are observed if necessary. Detailed information regarding the event and the patient's medical history should be obtained, and the emergency physician or burns surgeon where the patient is to be transferred should be informed of the burn severity and relevant medical history. Due to the expected edema formation in large burns, jewelry, including bracelets, rings and necklaces should be removed.

Burn wounds should not be covered with medicaments or substances on-

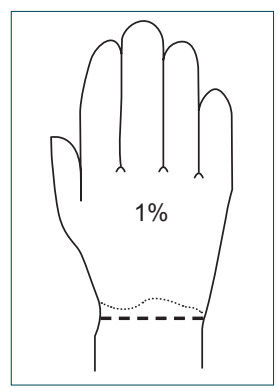

Figure 3. Practical estimation using palm. 


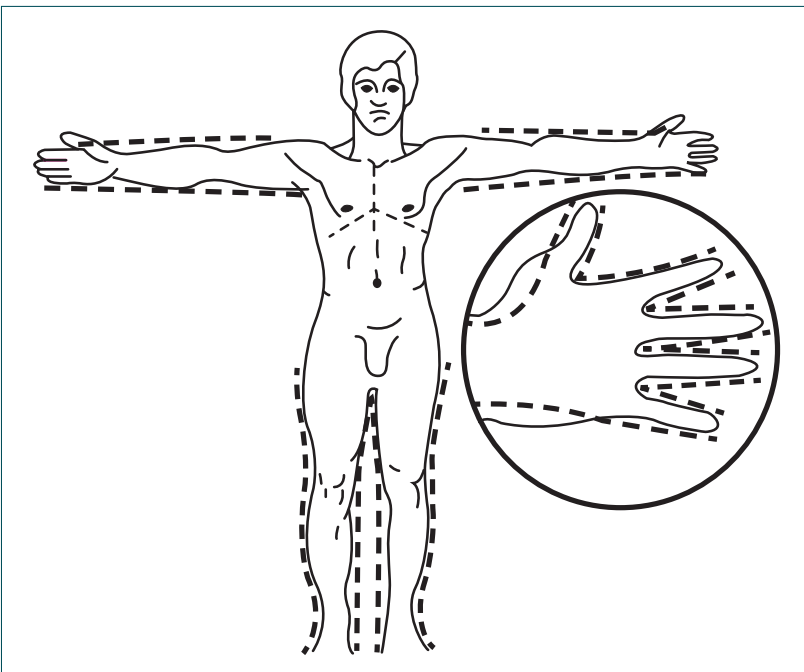

Figure 4. Escharotomy and/or fasciotomy sites.

site. Wrapping the burn wounds with a clean cloth is sufficient during transfer to the nearest emergency department. If available, medical coolants can be applied to the injury site during the transfer. In order to prevent systemic hypothermia, unburned body parts are covered to maintain body heat.

\section{Informing the Relevant Facility About the Burns Patient}

After the first medical attention, the following information must be delivered to the facility before transfer:

I. Age of the patient

2. Gender

3. The place and means of injury

4. Burning agent

5. Time of injury

6. Width and depth of the burn including involved body areas

7. Associated injuries

8. Co-morbidities

9. General medical status of the patient and the medical interventions performed

\section{Medical Attention in the Emergency Department}

The applications which should be attempted in the emergency department are summarized below:

I. Airway maintenance should be secured. Patient's respiratory distress, if any, should be relieved immediately, and endotracheal intubation should be performed with no delay where necessary or suspected. If required, tracheostomy should be performed for airway maintenance. In case of inhalation injuries; please see section 9.

2. Insert intra venous route.

- Wide burns require "central" catheterization. Subclavian vein is preferred to femoral catheterization.
- One or two effective peripheral venous line may provide sufficient venous access for children. However, for large burns requiring close monitoring, central catheterization is the optimum.

- If central catheterization is not possible in children younger than 6 years of age, a 16-18 gauge needle (spinal needle is compatible) can be inserted from the distal femoral or proximal tibial bone marrow (attention to the epiphysis plaque) under local anesthesia, and 100 $\mathrm{ml} /$ hour fluid can be delivered. Meanwhile, other intravenous routes can be tried.

- Temperature of the fluids should be close to the body temperature in order to avoid systemic hypothermia.

3. Associated traumas should be investigated and appropriately managed if present. If a multi-trauma patient has concomitant burns, the relevant department of the vital injury follows up the patient. In these patients, the participation of the burns surgeon in the management of the patient is as a consultant physician.

4. The patient's weight, height, and total body surface area in $\mathrm{m}^{2}$ (especially in children) should be assessed (see Table I). This assessment is the basis for fluid resuscitation and will also be a requirement for informing the burns facility regarding the severity of burn in case of a transfer. The "rule of nines" is generally reliable for calculating the burned body surface area in adults, but the Lund and Browder chart provides a better assessment for children. These charts should be placed in visible locations in the emergency departments where burns are managed.

5. Each burn case must be evaluated 'forensically' and if suspicious, should be reported to the police and/or forensic office.

6. In the pre-hospital period, covering the wounds with a clean dressing is sufficient. For a patient admitted to the emergency department, wound management will differ depending whether or not there is a requirement for hospitalization. Due to the expected edema formation in large burns, jewelry, including bracelets, rings and necklaces should be removed. Please see Section 3 outpatient burn wound management. Except for face burns, I\% silversulphadiazine is an option that can be considered for initiation without any disadvantage.

7. Intravenous fluid resuscitation should be initiated if the burned total body surface area is
a. $>10 \%$ in children
b. $>20 \%$ in adults

8. Fluid resuscitation in the emergency department:

Table I. Formulas proposed for child burns

Estimating the body surface area in children:

Body surface $\left(\mathrm{m}^{2}\right)=[4 \mathrm{x}$ body weight $(\mathrm{kg})+7] /[90+$ body weight $(\mathrm{kg})]$

Galveston's formula:

$2000 \mathrm{~mL} / \mathrm{m}^{2}$ body surface area $+5000 \mathrm{~mL} / \mathrm{m}^{2}$ burned body surface area 
The suggested formulas are in fact just recommending guidelines. Readjustments are required according to the clinical course of the patient.

- For adults, first 24 hours

- The Parkland Formula: 4 mL/kg/ \% burned TBSA, Ringer's lactate solution

- Modified Brooke's Formula: 2 mL/kg / \% burned TBSA

Half of the calculated amount is delivered over the first eight hours, and the remainder over the following 16 hours.

- For children, first 24 hours

- Galveston's formula: $2000 \mathrm{~mL} / \mathrm{m}^{2}$ body surface area + $5000 \mathrm{~mL} / \mathrm{m}^{2}$ burned TBSA, Ringer's lactate solution

Half of the calculated amount is delivered over the first eight hours, and the remainder over the following 16 hours.

9. Conditions requiring more fluid than calculated:

- Associated trauma,

- Alcoholic patient,

- Inhalation injury,

- Late onset or insufficient fluid resuscitation, dehydration,

- Electrical burns.

10. Urinary catheter should be placed in large burns and/or perineal burns requiring close monitoring. Targeted urinary output is;

Adult: $30-50 \mathrm{~mL} / \mathrm{hour}$

Child: $1-2 \mathrm{~mL} / \mathrm{kg} / \mathrm{hour}$

Targeted urinary density is 1015 .

In electrical burns and inhalation injuries, targeted urinary output should be twofold the above-mentioned volumes.

II. Applying pomades or creams containing local anesthetics to relieve pain is contraindicated.

12. The patient's pain will be relieved after dressing the burn. Please see Section 8 for pain management.

13. In chemical substance burns, burning continues as long as the active substance is in contact with the skin. After completely undressing, the patient is showered with running water at body temperature, but should not be put in a bathtub. Hypothermia should be avoided during a long lasting bath. See Section 6.

14. Electrical burns, chemical substance burns, and large and/ or deep burns should be hospitalized. Serum electrolytes and arterial blood gas, and if necessary, ECG follow ups should be applied.

15. In high voltage electricity burns, intravenous (iv) fluid should be delivered until the urine clears and becomes alkaline. See Section 7.

16. In case of edema and/or eschar tissue formation, the thorax, abdomen, extremities, and neck should be evaluated for the requirement of escharotomy or fasciotomy. See Section 5.

17. There is gastro-paralysis and ileus risk for unconscious patients and/or patients with burned TBSA $>30 \%$, indicating nasogastric decompression when necessary.

18. In patients with moderate or large burns and patients with high risk co-morbidities and/or concomitant injuries, essential blood and urinary tests should be performed (cross match, Rh test, serum electrolyte, blood glucose, complete blood count, myoglobinuria/hemoglobinuria, at least)

For patients with large burns, prophylaxis is applied according to general tetanus prophylaxis protocols.

\section{Patients Requiring Hospitalization}

- At all ages, second and third degree burns with burned TBSA $>20 \%$

- At all ages, third degree burns with burned TBSA $\geq 5-10 \%$,

- Patients younger than 10 or older than 50 years of age with second and third degree burns and with burned TBSA $\geq 10 \%$

- Burns of the face, ear, hand and foot

- Burns including major joints

- Burns of genitalia and perineum

- Chemical burns

- Electrical burns

- Lightning strike

- Inhalation injuries

- Associated multiple traumas

- Chronic co-morbidities (diabetes, hypertension, cardiac disease, immune deficiency, neurologic disorders)

- Pregnancy

- Presence or suspicion of child abuse.

\section{Local Wound Care for Burns}

Primarily, indication for hospitalization or outpatient management of the patient should be determined (See Section 2). Burns requiring surgical debridement, escharoectomy or fasciotomy, complicated large burns indicating serious fluid resuscitation, and deep burns likely to need grafting will not be covered in this section. Therefore, application of sophisticated treatment modalities including synthetic temporary coverings will be left to the facilities experienced in burns management. The treatment modalities described below are for patients who will be managed in outpatient polyclinics or burns rooms.

Outpatient follow-up criteria to be considered for patient management in polyclinic settings:

- Need for intravenous fluid resuscitation should be dissolute

- There should be no ongoing complication

- Absence of sepsis must be verified

- Sufficient oral nutrition should be maintained

- Pain management should be provided with oral analgesics.

Dressing change-wound cleaning:

Wounds are rinsed with tap water or saline to clean the wound and remove debris, and except for neutral $\mathrm{pH}$ liquid 
soaps, antiseptic solutions and brushing should not be used.

Topical antimicrobial containing creams and pomades are not required for minor burns. Dressing with paraffin or ointment (e.g. nitrofurazone $0.2 \%$ pomade) impregnated gauze is adequate. Dressing materials should be prepared separately for each individual patient and should be for single use.

In the presence of infection or eschar and large burns, I\% silver sulphadiazine can be used. Application of silver containing agents should be terminated with visible epithelialization as it delays epithelialization.

\section{First degree burns}

- No need for any dressing or topical antibacterial agent.

- Moisturizing cream or ointment is sufficient. These agents will diminish inflammation and the feeling of pain aroused by the skin's desiccation and stretching. Analgesics can be prescribed.

- Patients with large first degree burns may require hospitalization for pain management and hydration.

\section{Second degree burns}

- Superficial Burns

- Paraffin impregnated woven fabrics decrease the pain of dressing changes as they will not stick to the wound.

- Polyurethane film sheets can be used in visible areas for aesthetics.

- If these are not available, dressing with paraffin or greasy emulsion (e.g. $0.2 \%$ nitrofurazone) impregnated gauze is appropriate.

Management of Blisters: Blisters which are small in size and/or unlikely to erupt may be left intact. Larger blisters should be drained or unroofing is followed up with scheduled dressing changing.

- Deep Burns

- Antibiotic containing creams (e.g., silver sulfadiazine, mupirocin, nitrofurazone) can be applied directly or underneath the paraffin impregnated gauze.

- In case of a delayed wound healing and exceeding three weeks patients should promptly be referred to a burns unit/centre as discoloration, hypertrophic scarring, keloid formation or contractures are likely to occur.

- Third and Fourth Degree Burns

- Spontaneous eschar separation occurs via the enzymatic products of the underlying bacteria. In sterile full thickness burns, eschar does not separate spontaneously. Spontaneous separation of the eschar is a sign of an infected wound.

- These patients usually require surgical intervention and should be referred to a burns unit/centre for hospitalization.

\section{Transport of the Burns Patient}

Burns patient is a traumatized patient and it is vitally important that the transfer procedure is undertaken at the right time, to the right patient, and under the right conditions.

Burns patient is transferred in two ways:

I. Transfer to a healthcare facility from the scene

2. Transfer from one healthcare facility to another more experienced facility

The most important issues to be clarified before transferring a patient is the survival potential of the patient and the likelihood of the onset of a new life-threatening situation during transportation. Transportation is not a priority for a patient for whom survival is just subject to expectancies. Transportation of a patient with serious cardiopulmonary instability is also not a priority. However, there should never be a delay in transfer for a patient with the potential to survive, and transfer should be done as soon and quickly as possible.

\section{Patient Referral Criteria}

After determining burn severity, the decision is then taken as to which healthcare facility can manage the treatment (see Section I). Healthcare facilities which manage burns treatment according to the severity of the burns are polyclinics, burns rooms, burns units and burns centers according to the national burns treatment directorate. Minor burns are treated at outpatient clinics or can be hospitalized in a burns room. Moderate burns are treated in burns units in the absence of accompanying co-morbidities or when other injuries do not complicate the patients' general status. Severe/major burns are referred directly to a burns treatment center following their initial resuscitation at the first available healthcare facility. Nonetheless, if an existing co-morbidity or evolving situation complicates patient management during the clinical course, the patient should be referred to a higher level burns facility.

It is unacceptable, for whatever reason, to have uncontrolled transfer of the burned patient without applying initial medical attention as summarized in the booklet.

The two golden rules in patient transfer are good communication and effective team work. During the transfer:

I. Adequate stabilization of the burn patient should be secured before transferring.

2. The referred facility must be informed about the patient.

3. There must be direct communication between the physicians of the dispatching and accepting healthcare facilities.

4. The referral facility must confirm that they accept the patient.

The dispatching facility physician must forward the patient's information to the accepting facility physician, summarized as:

I. Age and gender

2. The place, time and source of injury 
3. Extent and depth of the burn, and burned body areas

4. Weight and height of the patient

5. Vital signs of the patient

6. Neurologic condition

7. Laboratory test results if any

8. Short medical history of the patient

9. Medical efforts already made after the injury

After having been given verbally, detailed written information should also be put in the patient file.

The issues listed below should be completed before the patient transfer:

I. A large venous catheter, or two if available, should be inserted preferably via upper extremities and stitched with sutures (burned skin can be used if necessary).

2. A spontaneously ventilating patient should have nasal oxygen support. In case of clinical suspicion of airway obstruction, the patient should be promptly intubated and ventilator settings should be applied.

3. A urinary catheter should be inserted to monitor urinary output (adults $30 \mathrm{~mL} /$ hour, children I $\mathrm{ml} / \mathrm{kg} /$ hour although twofold level is required in electrical burns and inhalation injury).

4. Oral intake should be stopped and a nasogastric tube should be inserted.

5. All narcotics should be ceased.

6. For patients transferred in the first $\mathbf{2 4}$ hours following a burns injury, only lactated Ringer's solution is delivered (Ringer's lactate solution with dextrose is preferred for children younger than 2 years of age). The pre-transfer amount of fluid resuscitation is determined by the dispatching physician according to the burned total body surface area.

7. Continuous ECG and respiratory monitoring is required during transfer.

8. Wet dressings are avoided during transfer.

9. The patient should be kept as warm as possible.

\section{Transfer options}

Patient transportation should always be undertaken in coordination with the emergency patient transfer coordinator center (Phone no: II2).

Ground transportation is used for distances up to $100 \mathrm{~km}$. However, helicopter transportation can be an option for shorter distances depending on the severity of the victim.

Aeromedical transportation choice depends on the patient's condition, distance, and specific risks related to air transportation.

I. Nasogastric tube should be inserted before departure

2. Pneumothorax should be investigated, and if present, a chest tube should be inserted.

Helicopters are used for distances up to $220 \mathrm{~km}$ and fixed wing aircraft should be preferred for longer distances. However, the availability of a heliport or airport has to be considered.

\section{The First 24 Hours of Hospital Care for Severe Burns}

Systematic examination is mandatory, and first aid, pre-hospital and emergency department diagnostic efforts must be repeated. The topics below should be evaluated cautiously before the transfer of a high-risk patient to an experienced burns facility. The list below is a stepwise checklist for the first 24 hours:

I. Burned patients with associated trauma can be hospitalized at the burns unit/centre. However, if the associated trauma has a higher risk or is vital, the patient should be accepted in the related department or general surgical intensive care unit and monitored by the mortality risk related department. The burns surgeon should take role as a consultant.

2. Airway, circulation and respiration are revised at the time of admission. One special problem of the burns patient is that airway obstruction is likely to occur in the short term. The answer to the question 'Which patients require intubation for a permanent airway?' is clear. If the physician has any doubt, a permanent airway must be maintained. Otherwise edema may develop within hours, making it impossible to intubate or to perform a tracheostomy.

3. Respiration must be supported with nasal oxygen. Ventilator settings should be set by the physician for patients with a permanent airway.

4. Circulation is primarily examined by pulse and heart rate.

5. In the first 24 hours, resuscitative fluid volume is estimated by Parkland's or modified Brooke's formulas in adults and Galveston's formula in children (Table I). These formulas are just recommendations and are for initiation, and the infusion rate is modulated according to the patient's clinical course.

6. Urinary output is one of the most reliable parameters for the assessment of circulation in the early stages. A urinary output level of $30 \mathrm{~mL} /$ hour in adults and $1 \mathrm{~mL} / \mathrm{kg} /$ hour in children is the most important indicator of adequate circulation and resuscitation.

7. The suggested urinary output should be twofold in patients with electrical burns and inhalation injury. In severe electrical injuries in adults, 50 grams of mannitol and 2 ampoules of $\mathrm{NaHCO} 3$ should be administered intravenously as soon as possible.

8. More fluid delivery is required in patients with dehydration due to delayed fluid resuscitation and/or with inhalation injury.

9. Burns patients are prone to hypothermia. If it develops, it should be treated promptly and efficiently.

10. After admission, the patient should be examined systematically. Detailed re-examination can reveal possibly over- 
looked concomitant injuries. A detailed medical history is taken from the patient or relatives, keeping abuse, intent or neglect in mind, especially in cases of child burns, and a forensic consultation must be requested if appropriate.

II. When evaluating the neurological condition of the patient, the narcotic analgesic treatment which has already been administered should be considered. In patients who cannot maintain or will not maintain upper airway openness, a permanent airway must be provided.

12. A nasogastric tube is inserted to the patients with burned total body surface area (TBSA) $>30 \%$. Tube feeding should be started for stabilized patients in the early stage. It is sufficient to start with $10 \mathrm{ml} /$ hour infusion of enteral nutrition which can be increased with patient toleration.

13. Severe burn injuries may cause acute gastrointestinal ulcers in adults. Severely burned adult patients are likely to develop acute gastrointestinal system ulcers; therefore, prophylaxis for acute mucosal lesion with $\mathrm{H} 2$ receptor antagonists should be initiated. Enteral nutrition is also added to the acute mucosal lesion prophylaxis. There is no need for prophylaxis for children tolerating oral nutrition.

14. Severely burned adult patients require prophylaxis for deep vein thrombosis. Either heparin or low molecular weight heparin can be given.

15. Pain management is important in burns patients. Narcotic analgesics are preferred in the early stage. See the related section of the booklet for dosage.

16. In circumferential thoracic, abdominal or extremity burns, escharotomy or fasciotomy is applied when necessary. Escharotomy should ideally be performed promptly when it is required. In emergency conditions when the patient cannot be transferred to a burns unit/centre, escharotomy or fasciotomy can be performed in the current healthcare facility (Fig. 4).

17. There is no indication for prophylactic or preemptive treatment in the early stage. Diagnosis of infection is difficult in burns patients. Therefore, antibiotics should only be used where infection has been proven or is highly probable. However, infection control precautions should be taken at every stage of the patient's clinical course and treatment.

\section{Chemical Burns}

Chemical burns are considered in two main groups of acid and alkaline. Alkaline burns cause liquefaction necrosis, and can exclusively progress to deeper tissues.

\section{Basic Treatment Principles}

Emergency Treatment:

I. Rapidly remove all clothing.

2. Contaminated areas should be washed with water. In order to avoid hypothermia, irrigate at room temperature with water at body temperature. The duration of rinsing with running tap water can be extended up to 60 minutes.
Pain relief or dissipation can be the end point of washing.

3. Neutralizing agents should never be applied. This application can lead to a deepening of the burn by chemical reaction itself or by the produced heat.

4. In burns of chemical powders, irrigation may have unfavorable effects. Water may activate chemical powders. In these conditions, after cleaning the chemical powder with a brush, a dry cloth or a vacuum cleaner, the area should be irrigated with copious water.

5. If there is an ocular injury, the eyes must be irrigated for a long time with copious amounts of water. The patient should consult an ophthalmologist.

\section{Some Chemical Burn Agents}

I. Dry lime burns: To prevent heat generation, the agent is firstly cleaned with brushing and afterwards washed with water.

2. Mercury Compounds: As blister fluid contains mercury, they are unroofed.

3. Tar Burns: Tar causes burns both by its heat and by chemical irritation. A practical way to remove tar from the skin promptly and without causing additional damage is to apply ice cubes on the tarred area for 10-20 minutes. In the mean time, tar will freeze to a crusty layer and consequently can be peeled off.

4. Hydrofluoric Acid: These patients mostly work in the glass and steel industry or dry cleaners. Hydrofluoric acid penetrates the skin immediately and continues damaging until reaching a calcium rich tissue like bone. Even small, hydrofluoric acid burns can cause hypocalcaemia which would be enough for cardiac side effects to occur. Hydrofluoric acid burns larger than 10\% may be fatal. Topical application of gel containing calcium gluconate is an effective, quick and non-invasive first step treatment, but if it is not effective, intravenous calcium gluconate infusion is indicated.

\section{Radiation Burns}

Local radiation burns caused by high dose radiation (8- I0 Gy) are similar to thermal injuries except for the delay which may extend from a few days to a few weeks. Progressive and intractable pain is a typical symptom and a challenging issue in the treatment of the patient. For this injury, the patient is referred to a burns unit/center under proper conditions.

\section{Electrical Burns}

Although injuries at lower than $1000 \mathrm{~V}$ are accepted as low voltage electrical burns and higher than $1000 \mathrm{~V}$ as high voltage electrical burns, even in electrical burns at 250-1000V, patients can suffer from unconsciousness, compartment syndrome, myoglobinuria, and hemoglobinuria. Therefore, these patients should be followed up in the same way as for high voltage injuries.

\section{Emergency Treatment Algorithm}

I. Within the context of a general trauma algorithm, the 
first priority is to check the circulation, assess airway, and breathing.

2. In low voltage electrical burns, atrial fibrillation with high ventricular response is the most encountered rhythm disorder and cause of death. Therefore, every patient with an electrical burn should have an ECG test. Cardiac monitoring and if possible, serum CPK-MB testing is indicated. Cardiac muscle necrosis may occur especially in a high voltage injury, and Troponin-I levels should be examined. If the electric flow trace crosses the heart, 24 hours cardiac monitoring is indicated.

3. Circulation disorder or severe muscle damage may occur in the extremities. Developing edema can cause compression of the muscles and necrosis (compartment syndrome). In such a case, escharotomy is insufficient and fasciotomy is indicated.

4. Strong contraction of electricity may result in muscle avulsion or shearing. Bone fractures or joint dislocations may be seen. Intra-abdominal visceral damage may also occur.

5. Myoglobinuria or hemoglobinuria may occur and to prevent acute renal failure, fluid resuscitation and urinary output monitoring is essential.

6. If the urine is black or red, the amount of fluid delivery should be increased immediately. In these patients, targeted output is $100 \mathrm{~mL} / \mathrm{h}$ in adults and $3-4 \mathrm{~mL} / \mathrm{kg} / \mathrm{hour}$ in children.

7. In order to alkalinize the urine, $\mathrm{NaHCO}_{3}$ is intravenously delivered 2 ampoules in adults, I ampoule for children heavier than $10 \mathrm{~kg}$ and $1 \mathrm{~mL} / \mathrm{kg}$ for children lighter than 10 $\mathrm{kg}$.

8. Diuretics are contraindicated in the acute stage, fluid delivery should be increased.

9. If attempts to provide osmotic diuresis fail, mannitol can become an option. The intravenous bolus dose is $50 \mathrm{~g}$ for adults and $0.5 \mathrm{~g} / \mathrm{kg}$ for children.

10. At high voltage electric burns, following the initial resuscitation, accompanying mortal injuries should be taken under control. After achieving complete control of mortal injuries or complications and full stabilization, the patient should be referred to the nearest available burns unit/center.

\section{Maintaning Analgesia for the Burns Patient}

I. Instillation of tap water $\left(20-25^{\circ} \mathrm{C}\right)$ to the burned area is important for both pain relief and dispersion of the heat accumulated in the tissues.

2. Hypothermia should be prevented in extensively burned patients, and unburned body parts should be covered to keep the patient warm. Ice and other coolants should not be used.

3. Intravenous opioids are administered to relieve stress induced anxiety in the early stage. Due to local vasoconstriction, the intravenous route is the first choice, although if not possible intramuscular or subcutaneous injections, respectively, can be used.

4. Morphine delivery with steady increments until relief of pain is the most-preferred method. In patients with respiratory injury, opioids can only be an option with close monitoring and/or mechanical ventilator.

5. Drugs should be titrated carefully and delivered by slow infusion to minimize probable respiratory and hemodynamic side effects while providing the adequate analgesic dose.

6. Tramadol and ketamine are reliable in various surgical approaches such as escharotomy of full thickness burns. Ideally, escharotomy/fasciotomy procedures should be applied at a burns unit/center.

7. In children or stressed adults, it is more convenient to make procedures requiring surgery under general anesthesia and in a burns unit/center.

\section{Acute Stage Analgesic Drugs and Intravenous Doses}

Drug Dose Duration

$\begin{array}{lll}\text { Tramadol (12 years and older) } & \mathrm{Img} / \mathrm{kg} & 4-6 \text { hours } \\ \text { Ketamine } & 0.2-0.5 \mathrm{mg} / \mathrm{kg} & 15-25 \text { minutes } \\ \text { Morphine or diamorphine } & 0.03-0.1 \mathrm{mg} / \mathrm{kg} & \\ & \text { child } 0.1 \mathrm{mg} / \mathrm{kg} & 4-6 \text { hours } \\ \text { Fentanyl } & \mathrm{I}-1,5 \mu \mathrm{gr} / \mathrm{kg} & \\ & \text { child I } \mu \mathrm{gr} / \mathrm{kg} & 45-60 \mathrm{~min} \\ \text { Meperidine } & 0.5-1 \mathrm{mg} / \mathrm{kg} & 2-4 \text { hours }\end{array}$

\section{Suggested Treatment Combinations}

I. For adults and children, fentanyl $0.5-\mathrm{I} \mu \mathrm{gr} / \mathrm{kg} / \mathrm{hour}+\mathrm{mi}-$ dazolam $0.03 \mathrm{mg} / \mathrm{kg} /$ hour can be an appropriate combination.

2. For adults with unstable respiration and hemodynamics, ketamine $0.5 \mathrm{mg} / \mathrm{kg}$ slow intravenous delivery is followed by tramadol $100-150 \mathrm{mg} / 2-4$ hours infusion during transportation.

3. In children younger than 12 years of age, ketamine $0.5 \mathrm{mg} /$ $\mathrm{kg}$ slow intravenous and fentanyl l $\mu \mathrm{gr} / \mathrm{kg} / \mathrm{hour}$ intravenous infusion is preferred. In children older than 12 years of age, ketamine $0.5 \mathrm{mg} / \mathrm{kg}$ slow intravenous and tramadol $100 \mathrm{mg} / 2-4$ hours infusion is appropriate.

4. Doses should be repeated 15-20 minutes before the expected end of the analgesic effect time.

Analgesic Drugs and Dose Recommendations for Outpatient Treatment

Adult Patient:

Non steroid anti-inflammatory drugs (i.e., naproxen, oxicam group) can be preferred.

Child Patient:

Paracetamol: $\quad 10-15 \mathrm{mg} / \mathrm{kg}$, par oral

Ibuprofen: After 2 years old, $20 \mathrm{mg} / \mathrm{kg} /$ day for 3-4 times a day, par oral. (Not suggested under 2 years old) 
Diagnosing Inhalation Injury

and Early Stage Treatment

Inhalation injury is defined as three different injuries arising

from the inhalation of thermal and/or chemical irritants:

I. Thermal injury affecting mostly the upper respiratory system

2. Chemical injury affecting the respiratory system as a whole

3. Systemic toxicities associated with the inhalation of toxic products such as carbon monoxide or cyanide.

Although more frequent with indoor burns, breathing smoke can create a serious risk of inhalation injury even outdoors. Serious inhalation injury may occur in the absence of skin burn!

\section{Clinical signs of inhalation injury}

I. Worsening of the general status of the patient, disordered consciousness, cyanosis, burns of the hair on the face, ear and nose, hoarseness, oral mucosal edema, carbon particles, and black sputum.

2. Perioral or facial burns, circumferential neck burns.

3. Signs of respiratory distress: tachypnea, dyspnea, stridor, wheezing

4. Signs of carbon monoxide intoxication: headache, dizziness, nausea, fatigue, distraction, chest pain, palpitation, visual disorders, abdominal pain, loss of consciousness.

Clinical management of a patient with inhalation injury

I. First priority is to ensure safety of the environment by removal from the scene and decontamination of the patient.

2. Airway maintenance and security (resuscitation position, airway insertion, control of the tongue's back sliding)

3. Breathing assessment (in case of superficial, apneic, and/ or obstructive breathing, support respiration with nasal cannulation/mask/endotracheal intubation)

4. Circulation assessment (fluid resuscitation, electrolyte replacement, warming, cardiovascular supportive medication)

5. During transportation, high flow $(5-6 \mathrm{l} / \mathrm{min}) 100 \%$ oxygen support via nasal cannula/mask.

6. When airway safety is not provided (facial or perioral burns, circumferential burns of the neck, progressive hoarseness, respiratory depression, loss of consciousness or sub-glottal edema); endotracheal intubation and/or mechanical ventilation should be applied.

\section{Transferring a patient with inhalation injury}

A patient with spontaneous ventilation or under mechanical ventilation support can be transported in every ambulance vehicle in which the required monitoring and adequate resuscitation can be provided.

\section{Clinician's Medicolegal Power and Child Abuse}

I. All burned patients should be evaluated forensically. It is obligatory in our country to complete a forensic record for all patients at mortality risk and all injuries clearly or suspiciously non-accidental, and to report this to the relevant authorities.

2. If the family or patient himself does not give written consent for treatment of a burns victim (accidental or abuse), medical care cannot be applied as long as the patient is conscious.

If the patient is conscious, lucid and has the ability to make his own declaration of intent, and even after being informed about all the risks, still has the right to reject treatment. However, a detailed consent form should be signed against possible future charges of malpractice or negligence. The patient should give a signed statement confirming that he has read and understood the facts and the risks, and if possible, (not compulsory) the signatures of two relatives, as witnesses, should be obtained.

3. Consent of the parents and/or legal guardian is mandatory for every sort of medical attention to children (except for emergent and life threatening conditions).

4. The family or official guardian or legal custodian of the child has the right to take their child to another healthcare facility after written consent. In cases of a help request, the available services should be provided.

5. If there is a life-threatening injury or the family insists on taking the child to another center even if there is no other available, the case should be reported to the forensic department and to the district attorney as there may be child abuse.

(Patient rights regulation, section 24: Patient's consent is required for medical attention. If the patient is a child or incapacitated then permission is taken from the parents or legal guardian. If the patient's parents or legal guardian is absent or not available or the patient has no power of expression, this condition is not required. Under conditions where the legal representative does not give consent, if the intervention is essential, the decision is given by the court. If taking the parents' or court's permission will take time and the condition is vital or a vital organ is at risk and needs immediate medical intervention, permission is not required.)

6. The forensic approach to accidental and non-accidental injuries is no different. The case is reported to the hospital police if available, or if not, to the nearest forensic department.

\section{Child Abuse}

The general approach is to keep the possibility of abuse in mind.

\section{Indicators of possible abuse in medical history}

I. Unexplained delay in getting the child to hospital

2. Discrepancy in medical history

3. Conflict between the medical history and physical exami- 
nation findings

4. More than one suspicious trauma history and different explanations of the parents

5. Parents' blaming a brother/sister or another third person for the accident

6. Blaming the child for the accident

7. Transporting the child to many different hospitals

8. Child accusing parents

9. Parents' past history of being abused in childhood

I0. Parents' unreal expectations from the child.

Indicators of possible abuse on physical examination:

I. Unique signs indicating punishment (ecchymosis on the back, legs, or genitalia). Different lesions at various healing stages.

2. Cigarette burns, scald burns on the hands or feet, perineum or hips

3. Abdominal trauma leading to rupture of the liver or spleen

4. Subdural hematoma with or without cranium fracture

5. Radiologic findings (subperiostal bleeding, decomposition of the metaphysis, periosteum ruptures or calcifications)

Helpful indicators for diagnosis:

I. Delay in medical assistance request (sometimes parents may never consult a doctor)

2. Unreliable medical history lacking details, differences in between the people or a changing history at each telling.
3. History cannot explain the damage observed

4. Parents' suspicious attitudes (mostly thinking about themselves, such as asking when they would be able to leave)

5. Parents' hostile behavior

6. Abnormal outlook of the child and abnormal relationship between the child and the parents

7. Child's explanations. A private interview with the child in an environment where the child can feel safe will be very helpful at diagnosis.

It is very important to have a written record of the questions and answers at anamnesis.

Pathognomonic signs of child abuse:

I. The child is extremely sensitive or inversely insensitive. $\mathrm{He}$ is not very sensitive to painful stimulus.

2. Clinical findings of the lesions indicating an occurrence time earlier than the proposed time.

3. Presence of different types of burns and incisions together.

4. Presence of various lesions of one source (i.e. many cigarette burns)

5. Attempts to hide lesions in different ways (covering the region with hair or bandage)

6. Lesions in unusual areas such as the tongue, lips, frenulum.

Conflict of interest: None declared.

\section{DERLEME - ÖZET}

\section{Yanık yaralanmaları tedavi algoritması}

Dr. Ahmet Çınar Yastı,,${ }^{1,2}$ Dr. Emrah Şenel, ${ }^{3}$ Dr. Mutlu Saydam, ${ }^{4}$ Dr. Geylani Özok, ${ }^{5}$ Dr. Atilla Çoruh, ${ }^{6}$ Dr. Kaya Yorgancı

${ }^{1}$ Hitit Üniversitesi Tıp Fakültesi, Genel Cerrahi Anabilim Dalı, Çorum;

${ }^{2}$ Ankara Numune Eğitim ve Araştırma Hastanesi, Yanık Tedavi Merkezi, Ankara;

${ }^{3}$ Yıldırım Beyazıt Üniversitesi Tıp Fakültesi, Çocuk Cerrahisi Anabilim Dalı, Ankara;

${ }^{4}$ Yunus Emre Devlet Hastanesi, Estetik Plastik ve Rekonstrüktif Cerrahi Kliniği ve Yanık Ünitesi, Eskişehir;

${ }^{5}$ Ege Üniversitesi Tıp Fakültesi, Çocuk Cerrahisi Anabilim Dalı, İzmir;

${ }^{6}$ Erciyes Üniversitesi Tıp Fakültesi, Estetik Plastik ve Rekonstrüktif Cerrahi Anabilim Dalı, Kayseri;

${ }^{7}$ Hacettepe Üniversitesi Tıp Fakültesi, Genel Cerrahi Anabilim Dalı, Ankara

Yanık yaralanmaları diğer pek çok ülkede olduğu gibi Türkiye'de de üzerinde durulması gereken bir sağlık problemidir. Bu hastaların erken dönem yönetimleri sonraki dönem morbiditesi ve mortalitesi için çok önemlidir. Bu nedenle Sağılı Bakanlığı, Yanık Bilim Komisyonu katkılarıyla hazırlanan "Ulusal Yanık Tedavi Algoritması"nı hazırladı. Bu algoritmanın temel amacı, yanık kazazedeleri deneyimli yanık merkezlerine ulaşana değin klinisyenlere kılavuzluk yapmaktı. Bu algoritmanın içeriği ilk yardım, başlangıç yönetimi, resüsitasyon ve transfer politikasıdır. Konsey, algoritma üzerindeki çalısmalarına 20II yılında başladı. Genel cerrahların, çocuk cerrahlarının, estetik plastik ve rekonstrüktif cerrahların, anestezistlerin ve yoğun bakım klinisyenlerini içeren çok sayıda konsültanlar ilk taslağı hazırladı ve bu sekiz Sağık Bakanlığı eğitim ve araştırma hastanesine, dört üniversiteye ve yedi sivil toplum kuruluşuna iletildi. 2012 yılının son çeyreğinde, algoritmaya son şekli verildi ve Bilim Komisyonu tarafından onaylandı. Sonrasında Sağlık Bakanlığı tarafından onaylanarak yayınlandı.

Anahtar sözcükler: Algoritma, klavuz; tedavi; yanık.

Ulus Travma Acil Cerrahi Derg 2015;2I (2):79-89 doi: 10.5505/tjtes.2015.8826I 